\title{
From Big Data to Mask Diplomacy: Taiwan's Effort to Strengthen International Role
}

\section{Dari Integrasi Mahadata ke Diplomasi Masker: Upaya Taiwan Meningkatkan Peran Internasional}

\author{
A. Safril Mubah \\ Universitas Airlangga \\ Sarah Anabarja \\ National Chengchi University
}

\begin{abstract}
ABSTRAK
Dengan mengandalkan ketahanan domestik tanpa dukungan komunitas internasional, Taiwan yang terkucil dari pergaulan dunia berhasil mengendalikan pandemi COVID-19. Meskipun Taiwan memiliki kedekatan geografis dengan China yang menjadi pusat bermulanya wabah COVID-19, negara ini hanya mencatatkan 467 total kasus COVID-19. yang terkonfirmasi hingga 31 Juli 2020. Melalui respons cepat berbasiskan integrasi mahadata, Taiwan mampu mencegah penularan COVID-19 yang lebih luas. Ketika situasi kesehatan domestik telah terkendali, Taiwan mulai melancarkan aksi global dengan mendonasikan masker medis ke berbagai negara. Diplomasi masker merupakan upaya yang ditempuh Taiwan untuk meraih citra positif di panggung dunia. Dalam artikel ini, penulis menemukan bahwa keberhasilan strategi Taiwan dalam menangani pandemi di tingkat domestik mendorong Taipei berupaya terlibat aktif dalam tata-kelola kesehatan global demi meningkatkan peran internasionalnya. Namun, upaya itu terhadang oleh isolasi diplomatik yang terus dilakukan China sejak Tsai Ing-wen menjabat sebagai presiden pada 2016. Untuk membahas isu tersebut, artikel ini terbagi menjadi tiga bagian. Pertama, kecepatan respons Taiwan dalam mencegah penularan COVID-19. Kedua, ketepatan strategi Taiwan dalam menyelesaikan pandemi sehingga melejitkan citra negara ini di tataran global. Ketiga, tantangan Taiwan untuk meningkatkan peran internasional di tengah isolasi diplomatik.
\end{abstract}

Kata-kata Kunci: kecepatan respons, integrasi mahadata, diplomasi masker, peran internasional.

As a diplomatically isolated country, Taiwan cannot lie to the international community in combating the COVID-19 pandemic. This situation is supposed to be obstacles for Taiwan, but the country can successfully control the COVID-19 pandemic thanks to its domestic resilience. Despite its geographic proximity with China, Taiwan has only confirmed 467 COVID-19 total cases by July 31, 2020. Through quick response based on big data integration, Taiwan has prevented COVID-19 from spreading around the country. While Taiwan can control its domestic situation, the government begins to launch global action for donating medical masks to many countries. Through mask diplomacy, Taiwan is expected to gain a positive image on the globe. Following its success in dealing with the pandemic at the local level, Taiwan is getting involved in global health order to improve its international role. However, this effort is challenged by diplomatic isolation imposed by China since President Tsai Ing-wen was in her office in 2016. This paper examines the issue and consists of three sections-first, Taiwan's quick response in preventing COVID-19 transmission. Second, Taiwan's strategy in dealing with the pandemic. Third, Taiwan's challenges in improving its international roles.

Keywords: quick response, big data integration, mask diplomacy, international role. 
Ketika Taiwan melaporkan kasus pertama virus Sars-Cov-2 pada 21 Januari 2020, negara ini diprediksi bakal mengalami dampak pandemi COVID-19 yang lebih buruk dibandingkan negaranegara lain. Prediksi itu muncul berdasarkan fakta bahwa Taiwan hanya berjarak sekitar 130 kilometer dari China, setiap hari ada penerbangan langsung dari Taipei ke Wuhan yang menjadi titik episentrum wabah COVID-19, sekitar 850 ribu dari total 23,78 juta warga negara Taiwan tinggal di China, dan sepanjang akhir Januari 2020 pergerakan manusia antarkedua wilayah negara itu sangat masif karena mereka pulang kampung untuk merayakan tahun baru Imlek.

Namun, Taiwan berhasil membalikkan prediksi tersebut dan justru menjadi contoh kesuksesan penanganan pandemi. Tujuh bulan setelah pandemi berlangsung, Taiwan hanya mencatatkan 467 total kasus COVID-19 dan menyisakan 19 kasus aktif pada 31 Juli 2020 (Gambar 1). Di antara total kasus itu, 412 kasus berasal dari ekspatriat Taiwan yang pulang kembali ke negaranya dan orang asing yang berkunjung ke Taiwan. Artinya, hanya 55 orang yang terinfeksi melalui transmisi lokal, dan penularan itu terakhir kali terjadi pada 13 April 2020.

Jumlah kasus COVID-19 di Taiwan jauh di bawah negara-negara tetangga yang juga memiliki kedekatan geografis dengan China seperti Jepang dan Korea Selatan yang memiliki puluhan ribu kasus. Ketika kasus di negara-negara tersebut terus meningkat, kasus di Taiwan menurun sejak Mei 2020. Berdasarkan data Taiwan Centers for Disease Control (CDC), penambahan kasus bulanan menurun dari 13 kasus pada Mei 2020 menjadi 5 kasus pada Juni 2020. Tantangan muncul ketika dilonggarkannya kontrol perbatasan menyebabkan peningkatan 20 kasus pada Juli 2020, sejalan dengan melonjaknya kasus di tingkat global. 


\section{Gambar 1}

\section{Perkembangan Kasus COVID-19 di Taiwan}

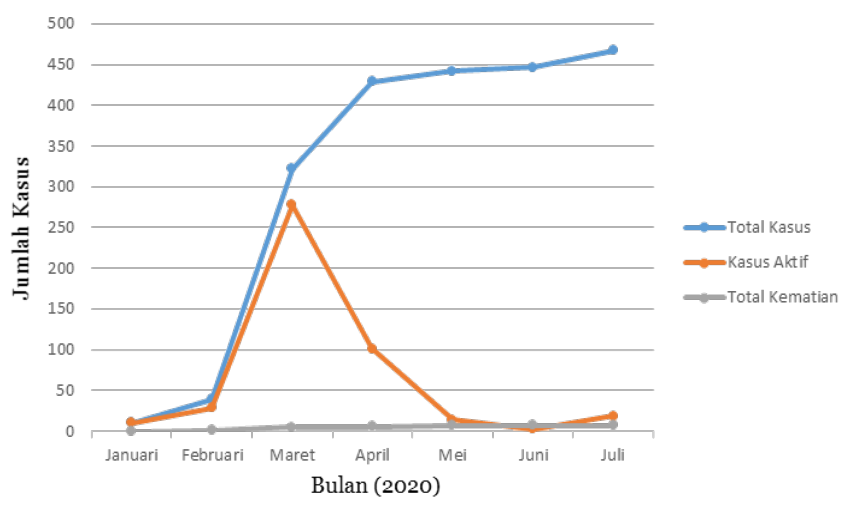

Sumber: Taiwan Centers for Disease Control (2020)

Sejak awal, Taiwan menghadapi tantangan tersumbatnya arus informasi penanganan pandemi COVID-19 di tataran global akibat tidak dilibatkannya negara ini dalam pertemuan-pertemuan Badan Kesehatan Dunia (WHO). Dampaknya, Taiwan terpaksa bekerja sendiri tanpa bantuan komunitas internasional. Meski demikian, hal itu tidak menyurutkan langkah Taiwan memerangi COVID-19 hingga mendapatkan pujian banyak negara atas keberhasilannya melawan pandemi. Kesuksesan itu mendorong Taiwan mempromosikan model penanganan pandemi ke dunia melalui diplomasi masker.

Pemerintahan Presiden Tsai Ing-wen berharap diplomasi masker mampu meningkatkan citra positif Taiwan di panggung dunia. Persoalannya, upaya Tsai meningkatkan peran internasional Taiwan terhadang oleh isolasi diplomatik yang terus dilancarkan China. Dalam konteks hubungan internasional masa pandemi, kajian tentang strategi aktor internasional yang terkucil dalam menangani COVID-19 secara domestik dan upayanya memperkenalkan strategi itu ke tingkat global merupakan isu strategis yang relevan dibahas dalam artikel ini.

Strategi dan tantangan tersebut dielaborasi melalui tiga bagian. Pertama, kesiapan dini Taiwan dalam menghadapi pandemi yang 
From Big Data to Mask Diplomacy:

Taiwan's Effort to Strengthen International Role

berkontribusi pada kecepatan respons terhadap merebaknya wabah COVID-19. Kedua, tahapan strategi Taiwan yang berawal dari integrasi mahadata hingga diplomasi masker. Ketiga, tantangan yang dihadapi Taiwan dalam mempertahankan keamanan kesehatan domestik yang telah terkendali dan dalam meningkatkan peran internasional.

\section{Kecepatan Respons}

Pengalaman buruk ketika dihantam wabah Severe Acute Respiratory Syndrome (SARS) pada 2003 membuat Taiwan cepat menanggapi kemungkinan penularan COVID-19 ketika penyakit ini mulai merebak di China pada Desember 2019. Berdasarkan data pemerintah China yang diungkap oleh South China Morning Post (Ma 2020), kasus pertama COVID-19 terjadi di Wuhan pada 17 November 2019. Dalam kurun waktu 1,5 bulan hingga 31 Desember 2019, 266 orang di China telah terinfeksi virus SarsCov-2. Ketika pemerintah China menutupi arus informasi di masa awal munculnya wabah, pemerintah Taiwan telah mengetahui merebaknya penyakit mirip SARS melalui diskusi daring di dunia maya.

Belajar dari dampak buruk SARS, pada 2004, pemerintah Taiwan mendirikan National Health Command Center (NHCC) sebagai bagian dari pusat manajemen bencana yang khusus menangani wabah penyakit dan bertindak sebagai pusat komando operasional. Di bawah naungan Kementerian Kesehatan dan Kesejahteraan, NHCC terdiri dari Central Epidemic Command Center (CECC), Biological Pathogen Disaster Command Center, CounterBioterrorism Command Center, dan Central Medial Emergency Operations Center. Bersama CDC, CECC memiliki peran penting mengendalikan wabah COVID-19. Dibentuk pada 2008, CECC difungsikan CDC secara khusus ketika wabah penyakit merebak. Dipimpin Menteri Kesehatan dan Kesejahteraan Chen Shih-chung, CECC mengoordinasikan upaya semua institusi untuk mencegah memburuknya krisis kesehatan masyarakat.

Sebelum wabah, CDC telah melakukan sistem pengawasan menyeluruh yang mengintegrasikan informasi dari aneka sumber. 
Ketika wabah terdeteksi melalui pengawasan media sosial, tim pengawasan Taiwan terus mengumpulkan informasi melalui perbincangan daring, laporan pemerintah, dan pernyataan pers resmi untuk memantau perkembangan harian di China. Informasi yang terkumpul itu menjadi bahan pertimbangan pengambilan keputusan, dan pemerintah Taiwan selalu memperbarui keputusan tersebut secara berkala disesuaikan dengan perkembangan di China.

Ketika situasi di China semakin memburuk, otoritas Taiwan mulai memeriksa suhu tubuh semua penumpang pesawat yang datang dari Wuhan pada 31 Desember 2019. Pemeriksaan dilakukan di dalam pesawat untuk memastikan semua orang yang akan masuk wilayah Taiwan terbebas dari gejala COVID-19. Pada 5 Januari 2020, otoritas Taiwan memeriksa semua individu yang memiliki riwayat perjalanan ke Wuhan selama 14 hari ke belakang. Mereka yang menunjukkan gejala demam harus melakukan karantina diri di rumah. Pada 20 Januari 2020, CDC mengaktifkan CECC yang lalu mengumumkan sejumlah kebijakan merespons memburuknya situasi kesehatan di Wuhan.

Menurut Cheng Hao-Yuan, Li Shu-Ying, dan Yang Chin-Hui (2020), pada fase awal pandemi, strategi Taiwan bersandarkan pada tiga pilar: (1) pengawasan langsung dengan penilaian risiko, (2) kontrol perbatasan dan karantina, dan (3) peningkatan kapabilitas laboratorium. Tiga pilar itu tecermin dalam 124 perangkat kebijakan yang dikeluarkan CECC pada 31 Desember 2019-24 Februari 2020. Di antara semua kebijakan tersebut, kebijakan yang paling berkontribusi signifikan untuk mencegah perluasan COVID-19 adalah: (1) identifikasi kasus menggunakan pelacakan riwayat perjalanan individu berbasis data digital dan teknologi informasi, dan (2) pengelolaan produksi dan distribusi masker melalui kolaborasi lintas sektor.

\section{Digitalisasi Informasi}

Semua kebijakan Taiwan berbasis riset ilmiah dan bertumpu pada kumpulan informasi yang tersimpan dalam mahadata (big 
data). Kumpulan informasi tersebut diolah secara digital melalui perangkat teknologi integratif yang menghubungkan data kependudukan, kesehatan, imigrasi, transportasi, dan mobilitas individu. Melalui integrasi mahadata digital, Taiwan mampu secara cepat melacak pergerakan pasien yang terinfeksi COVID-19 sekaligus orang-orang yang berinteraksi dengan pasien tersebut. Individu yang teridentifikasi dalam kelompok orang ini diwajibkan melakukan isolasi diri dan dipantau secara elektronik melalui nomor telepon seluler mereka.

Pemerintah Taiwan memberikan dukungan kepada pasien yang terinfeksi dan individu yang dikarantina dengan menyediakan berbagai layanan gratis. Pasien yang terinfeksi diisolasi di sejumlah rumah sakit, diperiksa secara berkala, dan diobati hingga sembuh. Individu yang dikarantina bisa melakukannya secara mandiri di rumah atau jika tidak memungkinkan ditampung di beberapa hotel yang telah ditunjuk pemerintah. Untuk mengurangi beban psikologis mereka, pemerintah lokal menyediakan layanan pengiriman makanan, pencucian pakaian, pembuangan sampah, dan pemeriksaan kesehatan. Melalui penyediaan layanan tersebut, pemerintah berharap individu yang dikarantina tidak keluar dari ruang karantina. Jika melanggar, pemerintah mengenakan denda antara 100 ribu dan 1 juta dolar Taiwan (setara dengan Rp 50500 juta). Sejumlah orang di berbagai kota telah didenda dengan jumlah bervariasi tergantung tingkat pelanggaran. Mereka yang menolak bakal ditahan di penjara selama beberapa bulan (Taiwan News, 30 Juli 2020; Hsu, 1 April 2020).

Otoritas Taiwan dengan mudah mengetahui pelanggaran tersebut lantaran jejaring monitor teknologi tinggi telah diciptakan untuk memastikan karantina diri benar-benar dilaksanakan oleh individu. Undang-Undang Pengendalian Penyakit memberikan CECC kekuatan legal untuk menjalankan sistem pengawasan tersebut. Setelah pandemi berakhir, sistem pelacakan akan berhenti berfungsi dan semua data pribadi akan dihapus. Setiap individu memiliki hak legal untuk meminta datanya dihilangkan dari sistem. Karena itu, masyarakat Taiwan meyakini data pribadi dan privasi mereka terlindungi (Lee dan Kuo 2020).

Melalui analisis mahadata, pada 27 Januari 2020 Badan Imigrasi 
Nasional (NIA) dan Badan Asuransi Kesehatan Nasional (NHIA) mengintegrasikan catatan perjalanan individu dengan data kartu NHI yang merekam riwayat kesehatan pasien. Sistem registrasi kependudukan Taiwan memungkinkan pemerintah melacak individu dengan risiko tinggi. Data penggunaan kartu NHI memungkinkan pemerintah mengetahui riwayat penyakit yang diderita pasien. Pasien yang pernah menderita demam tinggi dipanggil untuk menjalani pemeriksaan laboratorium. Uji laboratorium ini dilakukan berulang kali hingga dipastikan bahwa pasien benar-benar negatif COVID-19. Dengan metode ini, Taiwan mampu mendeteksi gejala COVID-19 lebih awal.

Pada 30 Januari 2020, pusat data NHIA meluaskan cakupan riwayat perjalanan 14 hari terakhir untuk pendatang dari China, Hong Kong, dan Makau. Mulai 14 Februari 2020, semua pendatang yang masuk wilayah Taiwan harus mengisi formulir pernyataan kesehatan secara daring dengan memindai kode respons cepat ( $Q R$ code). Langkah ini mengurangi antrean masuk di pintu imigrasi secara signifikan sehingga mengurangi risiko akibat berkumpulnya banyak orang. Empat hari kemudian, semua rumah sakit, klinik kesehatan, dan apotek di Taiwan dapat mengakses riwayat perjalanan pasien (Wang, Chun, dan Broad 2020).

Melalui digitalisasi informasi, Taiwan menjamin semua informasi terkait COVID-19 dapat diakses publik secara transparan. Setiap hari Menteri Chen menyelenggarakan konferensi pers untuk menginformasikan data terbaru kasus COVID-19 sekaligus kebijakan yang diputuskan pemerintah. Hasil dari konferensi pers itu diinformasikan secara terbuka melalui kanal-kanal resmi pemerintah dan disirkulasikan ke berbagai media. Melalui sistem yang transparan, Menteri Luar Negeri Joseph Wu (Bardi dan Bollyky 2020) meyakini bahwa "... we create a bond and a trust in between the government and the people, and when the government is telling the people that this is probably something you need to do, people will follow. And when the government says that there is something that we shouldn't be doing, the people will also follow." Pernyataan Menteri Wu mencerminkan adanya rasa saling percaya antara pemerintah dan masyarakat. Kepercayaan itulah yang mendorong semua pihak di Taiwan untuk disiplin mematuhi protokol kesehatan. 
From Big Data to Mask Diplomacy:

Taiwan's Effort to Strengthen International Role

\section{Kolaborasi Lintas Sektor}

Kerjasama yang baik antara pemerintah dan masyarakat mendorong terwujudnya kolaborasi lintas sektor yang melibatkan korporasi dan akademisi. Kemitraan antara sektor bisnis dan akademis terjalin erat. Dengan dukungan pemerintah, sejumlah perusahaan bioteknologi dan lembaga riset saling bekerja sama melakukan penelitian yang hasilnya berupa produk kesehatan. Beberapa perusahaan teknologi tinggi berkolaborasi dengan pemerintah untuk melakukan inisiatif "Taiwan can help" yang diluncurkan Presiden Tsai pada awal April 2020. Contohnya, ADE Technology Inc. memproduksi kamera pengukur suhu tubuh melalui teknologi pengenalan wajah dan mendonasikan kamera tersebut ke 15 negara yang memiliki hubungan diplomatik dengan Taiwan. IWEECARE meluncurkan termometer pintar terkecil di dunia yang dapat mengukur suhu tubuh banyak pasien dalam satu waktu dan terkoneksi dengan sistem pelacakan individu yang menjalani karantina di rumah (Lee dan Kuo 2020). Untuk menangani tes COVID-19 secara cepat, perusahaan-perusahaan di Taiwan mengembangkan sistem robotika agar mampu meningkatkan kapasitas tes (Wu et al. 2020).

Demi menghindari kelangkaan masker di pasar domestik, pemerintah melarang ekspor masker pada 24 Januari 2020 dan mengambil alih produksi dan distribusi masker seminggu sesudahnya. Untuk menggenjot produksi masker medis, pemerintah memberikan subsidi kepada perusahaan, merekrut seratus teknisi, dan mengerahkan personel militer ke berbagai lini produksi (Wang, Chang, dan Mazzetta 2020). Hasilnya, produksi masker meroket dari 1,88 juta ke 19,11 juta lembar per hari dalam waktu empat bulan (Lee 2020).

Untuk menjamin setiap penduduk memiliki masker medis secara merata, pemerintah memberlakukan kebijakan distribusi masker dan menunjuk apotek-apotek tertentu untuk menjual masker kepada konsumen. Pada 6 Februari-4 Maret 2020, setiap individu diizinkan membeli hanya dua masker setiap tujuh hari. Mulai 5 Maret 2020, batas maksimal masker yang bisa dibeli meningkat menjadi tiga lembar setiap tujuh hari. Mulai 9 April 2020, batas maksimal pembelian masker meningkat menjadi sembilan lembar setiap 14 hari. Mulai 3 Juni 2020, pemerintah mencabut larangan 
penjualan masker secara komersial sehingga toko-toko bisa menjual masker secara bebas dan konsumen juga bisa membelinya secara bebas.

Dengan produksi masker medis berlimpah, Taiwan mulai menyumbangkan masker ke negara-negara lain ketika pandemi di tingkat domestik terkendali. Ketika produksi masker mencapai 13 juta lembar per hari pada 1 April 2020, Presiden Tsai menyatakan Taiwan akan mendonasikan 10 juta masker ke negara-negara yang terdampak serius COVID-19. Menurut Tsai (Yang 2020), "Taiwan can hardly be left unharmed by the global pandemic, so we should collaborate with other countries in fighting the virus. ... We can't sit by and watch, we will provide masks, drugs, and knowhow to countries in need. ... Today, Taiwan not only can help but is helping."

Pernyataan Tsai merupakan momentum dimulainya kampanye "Taiwan can help" secara global. Kampanye ini dijalankan tidak hanya oleh pemerintah, tetapi juga melibatkan partisipasi masyarakat. Warga negara Taiwan diberikan kesempatan untuk turut menyumbangkan masker melalui aplikasi teknologi yang diciptakan pemerintah. Komunitas warga Taiwan menciptakan inisiatif di dunia maya untuk mengampanyekan "Taiwan can help" melalui situs www.taiwancanhelp.us. Mereka memobilisasi masyarakat untuk terlibat menyebarkan informasi tentang keberhasilan Taiwan mengatasi pandemi sekaligus menghimpun pengumpulan jutaan masker untuk disumbangkan. Data di situs ini mencatat 708.890 warga negara Taiwan telah mengumpulkan 5.851.474 masker untuk didonasikan ke berbagai negara.

Menurut Cheng-chia Tung (2020), kampanye "Taiwan can help" menunjukkan ketahanan nasional Taiwan di masa krisis kesehatan masyarakat tidak memunculkan nasionalisme sempit, tetapi justru mendorong penguatan solidaritas global. Di tengah isolasi internasional, Taiwan tidak menutup diri untuk berkutat hanya pada urusan domestik tetapi terus berupaya menyelesaikan krisis kesehatan global. Setelah mampu mengendalikan virus secara domestik, Taiwan mulai mendonasikan masker medis ke berbagai negara. Diplomasi masker ini menandai upaya Taiwan untuk kian meningkatkan peran internasionalnya. 
From Big Data to Mask Diplomacy:

Taiwan's Effort to Strengthen International Role

\section{Tantangan}

Melalui integrasi mahadata dan diplomasi masker, Taiwan memberikan contoh kepada dunia tentang strategi paling tepat mengatasi pandemi COVID-19. Strategi tersebut merupakan bagian dari kebijakan khas Taiwan yang dipuji dunia atas keberhasilannya mencegah meluasnya penularan COVID-19 dan menjadikan Taiwan sebagai negara paling aman di era pandemi. Taiwan mampu menjalankan kebijakan tersebut secara demokratis tanpa harus mengekang kebebasan warganya. Penyakit dapat dikendalikan tanpa perlu menutup wilayah. Masyarakat tetap dapat beraktivitas seperti biasa dan transaksi ekonomi terus berjalan tanpa henti. Perkantoran dan sekolah tetap buka tanpa harus merotasi waktu masuk pegawai dan pelajar seperti yang diterapkan di banyak negara.

Namun, keberhasilan strategi itu sedang diuji oleh tantangan yang mengintai. Seiring dengan keberhasilan Taiwan mengendalikan wabah, pada 7 Juni 2020, pemerintah mencabut aturan pembatasan sosial tetapi tetap mewajibkan warga menggunakan masker di tempat-tempat publik. Pelonggaran aturan ini sempat disalahartikan sebagian warga dengan mulai tidak menggunakan masker kecuali ketika menggunakan transportasi publik dan mengunjungi rumah sakit. Sejumlah orang juga mengabaikan anjuran pembatasan sosial di tempat-tempat publik. Ada kecenderungan, sebagian orang di Taiwan mengabaikan perkembangan virus di negara lain. Perilaku dan pandangan ini dapat berdampak buruk pada merebaknya ancaman peningkatan kasus gelombang kedua, apalagi jika muncul penularan domestik. Beberapa negara telah mengalami gelombang kedua, dan tidak ada jaminan Taiwan akan terbebas darinya (Cheng 2020).

Tantangan semakin besar lantaran Taiwan harus bekerja sendiri tanpa sokongan komunitas internasional. Status Taiwan sebagai negara yang tidak memiliki kedaulatan eksternal dan terus dikucilkan oleh China membuat Taipei sulit bergerak secara bebas dalam bekerja sama dengan organisasi internasional atau negaranegara lain. Pemerintah Taiwan selalu mengkritisi pengucilan internasional yang menyebabkan terbatasnya upaya Taipei untuk memainkan peran internasional lebih penting dalam jaringan sistem kesehatan global. 
Taiwan sebenarnya pernah terlibat sebagai pengamat dalam World Health Assembly (WHA) pada 2009-2016. China yang memiliki pengaruh sangat kuat di WHO berkepentingan untuk menyokong pemerintahan Kuomintang (KMT) yang berkuasa di Taiwan pada periode itu. Ketika kekuasaan KMT direbut Democratic Progressive Party (DPP) pada 2017, China menekan WHO untuk membatalkan partisipasi Taiwan di WHA dan berdampak pada hilangnya status Taiwan sebagai pengamat. Meskipun Taiwan terus berupaya terlibat kembali dalam WHA untuk memaksimalkan kontribusi dalam penanganan pandemi global, tetapi China selalu menghadang upaya tersebut. Upaya Taiwan untuk mendapatkan informasi terkini tentang COVID-19 dari WHO selalu terhambat dan informasi tentang merebaknya wabah COVID-19 di China yang dikirimkan Taiwan ke WHO juga diabaikan. Menurut Menteri Wu, pengabaian ini merupakan masalah serius karena Taipei ingin menerima informasi resmi dari WHO sehingga Taiwan dapat dilindungi oleh komunitas internasional ketika wabah penyakit terjadi dan Taiwan juga ingin mampu membantu komunitas internasional jika dibutuhkan (Bardi dan Bollyky 2020).

Ke depan, keputusan WHO untuk melibatkan Taiwan dalam upaya global penanganan pandemi atau bahkan memberikan keanggotaan kepada Taiwan sangat tergantung pada seberapa besar upaya yang diambil Taipei (Yu 2020). Diplomasi masker sangat ampuh meningkatkan citra positif Taiwan di dunia, terutama di negara-negara yang mendapatkan bantuan masker medis. Secara bilateral, Taiwan dapat turut berperan mengatasi wabah COVID-19 di negara mitranya melalui bantuan yang diberikan lewat jalur non-diplomatik. Namun, upaya memainkan peran internasional di organisasi multilateral seperti WHO akan sulit dilakukan selama pengaruh China terus menguat.

\section{Simpulan}

Walaupun terisolasi secara diplomatik, Taiwan memiliki kapasitas dalam mengatasi pandemi COVID-19 di tingkat domestik. Tanpa dukungan komunitas internasional, Taiwan mampu melindungi 
warganya dari penyebaran COVID-19 yang lebih luas. Kemampuan Taiwan untuk terhindar dari krisis kesehatan masyarakat ditunjang oleh kesiapan dini dalam menghadapi wabah penyakit. Selain ketersediaan fasilitas kesehatan yang canggih, kesiapan dini itu ditopang oleh tradisi masyarakat Taiwan untuk mencuci tangan dengan sabun dan menggunakan masker ketika sakit. Mahadata yang terintegrasi adalah simbol kecanggihan sistem layanan kesehatan. Kedisiplinan masyarakat dalam mematuhi protokol kesehatan sesuai anjuran pemerintah adalah bentuk rasa saling percaya masyarakat dan pemerintah yang memunculkan solidaritas komunitas untuk bekerja sama memerangi COVID-19.

Solidaritas komunitas itu mendorong upaya semua pihak untuk menjalin kolaborasi lintas sektor dalam memproduksi jutaan masker medis. Ketika situasi nasional terkendali, solidaritas ditingkatkan ke ranah global melalui donasi masker ke berbagai negara. Donasi masker merupakan bentuk diplomasi Taiwan untuk semakin meningkatkan peran internasional di tengah pengucilan dunia. Melalui diplomasi masker, Taiwan berhasil meningkatkan citra positifnya di tingkat global. Persoalannya, upaya untuk meluaskan peran internasional secara multilateral selalu terhambat oleh dominasi China di WHO. Inilah tantangan internasional terbesar yang dihadapi Taiwan di bawah kepemimpinan Presiden Tsai. Keberhasilan Taiwan dalam mengatasi tantangan itu sangat tergantung pada pilihan strategi yang diambil Tsai. Ketepatan strategi bakal mendongkrak peran internasional Taiwan sehingga berpotensi meraup dukungan diplomatik dari negara-negara lain. Kesalahan strategi dapat berujung pada semakin terkucilnya Taipei dalam kancah diplomasi global.

\section{Referensi}

\section{Jurnal dan Jurnal Daring}

Cheng, Hao-Yuan, Shu-Ying Li dan Chin-Hui Yang, 2020. "Initial Rapid and Proactive Response for the COVID-19 Outbreak - Taiwan's Experience," Journal of the Formosan Medical Association, 119: 771-773. 
Wang, Jason, Chun Y. Ng, dan Robert Brook, 2020. "Response to COVID-19 in Taiwan: Big Data Analytics, New Technology, and Proactive Testing," American medical Association, 33 (14): 1341-1342.

Yu, Ruei-lin, 2020. "Taiwan Demonstrates Healthcare Proficiency," Strategic Vision, 9 (45): 8-13.

\section{Sumber Resmi}

Taiwan Centers for Disease Control (CDC), 2020. https://www. cdc.gov.tw/En [diakses 31 Juli 2020].

\section{Artikel Daring}

Bardi, Jason Socrates dan Thomas J. Bollyky, 2020. “Taiwan's response to COVID-19 and the WHO: An interview with TaiwaneseMinisterofForeignAffairsJaushiehJosephWuon Taiwan's response to COVID-19 and the WHO," Think Global Health, 15 Mei [daring]. dalam https://www. thinkglobalhealth.org/article/taiwans-response-COVID19-and-who [diakses 30 Juli 2020].

Cheng, Ching-Tse, 2020. "Taiwan Doctors Warns of Potential Coronavirus Tsunami," Taiwan News, 28 Juli [daring]. dalam https://www.taiwannews.com.tw/en/ news/3975572 [diakses 29 Juli 2020].

Hsu, Sheng-lun, 2020. "Virus Outbreak: New Taipei City Man Fined, Taken to Quarantine Center," Taipei Times, April 1 [daring]. dalam https://www.taipeitimes.com/News/ taiwan/archives/2020/04/01/2003733788 [diakses 24 Agustus 2020].

Lee, I-chia, 2020. "CECC thanks mask makers, distributors," 3 Juni [daring]. dalam https://www.taipeitimes.com/News/ taiwan/archives/2020/06/03/2003737533 [diakses 30 Agustus 2020]. 
From Big Data to Mask Diplomacy:

Taiwan's Effort to Strengthen International Role

Lee, Chun-yi dan Yu-ching Kuo, 2020. "Taiwan Can Help!,” Taiwan Insight, 26 Juni [daring]. dalam https://taiwaninsight. org/2020/o6/26/taiwan-can-help/ [diakses 20 Juli 2020].

Ma, Josephine, 2020. "Coronavirus: China's First Confirmed COVID-19 Case Traced Back to November 17," South China Morning Post, 13 Maret [daring]. dalam https:// www.scmp.com/news/china/society/article/3074991/ coronavirus-chinas-first-confirmed-COVID-19-casetraced-back [diakses 29 Juli 2020].

Taiwan News, 2020. "Taiwanese Man Detained for Refusing to Pay Fines after Breaking Home Quarantine," $30 \mathrm{Juli}$ [daring]. dalam https://www.taiwannews.com.tw/en/ news/3976864 [diakses 24 Agustus 2020].

Tung, Cheng-Chia, 2020. "How Taiwan can Help Create a More Resilient Global Society," Taiwan Insight, 18 Mei [daring]. dalam https://taiwaninsight.org/2020/05/18/howtaiwan-can-help-create-a-more-resilient-global-society [diakses 27 Juli 2020].

Wang Chao-yu, Chung Jung-feng, dan Matthew Mazzetta, 2020. "How a Team of Technicians is Helping Taiwan Triple Mask Production," Focus Taiwan, 24 Maret [daring]. dalam https://focustaiwan.tw/society/202003240015 [diakses 24 Agustus 2020].

Wu, Wei-Kai et al., 2020. "Pandemic Preparedness in Taiwan," Nat Biotechnol [daring]. https://doi.org/10.1038/s41587020-0630-o [diakses 27 Juli 2020].

Yang, Sophia, 2020. "Taiwan Helps Defeat Coronavirus with Donation of 10 Million Masks," Taiwan News, April 1 [daring]. dalam https://www.taiwannews.com.tw/en/ news/3908478 [diakses 24 Agustus 2020]. 